\title{
67 Festival de Cine de San Sebastián. Nuevas miradas sobre la Guerra Civil
}

CORO RUBIO POBES (UPV/EHU)

Enviada especial

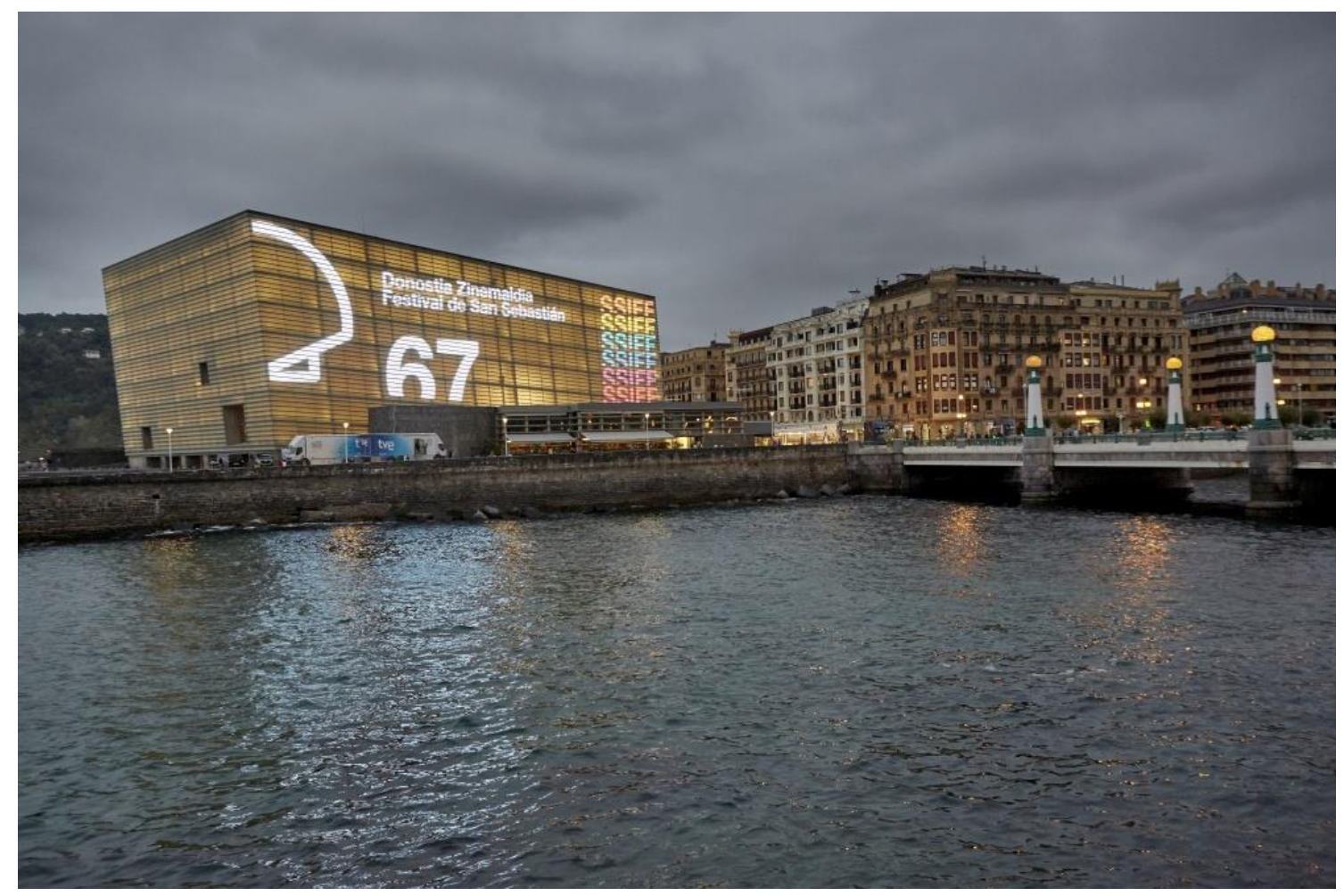


Pacificado, una producción brasileña dirigida por Paxton Winters (Texas, 1972) ha sido la triunfadora del 67 Festival Internacional de Cine de San Sebastián: Concha de Oro a la mejor película, Concha de Plata al Mejor Actor (Bukassa Kabengele) y Premio del Jurado a la mejor fotografía (Laura Merians), pulverizando las quinielas y desconcertando a buena parte de la prensa desplazada al festival, que ha acogido con frialdad la resolución de un jurado presidido por Neil Jordan. El film nos lleva a una de las favelas de Río de Janeiro en los días posteriores a los Juegos Olímpicos de 2016

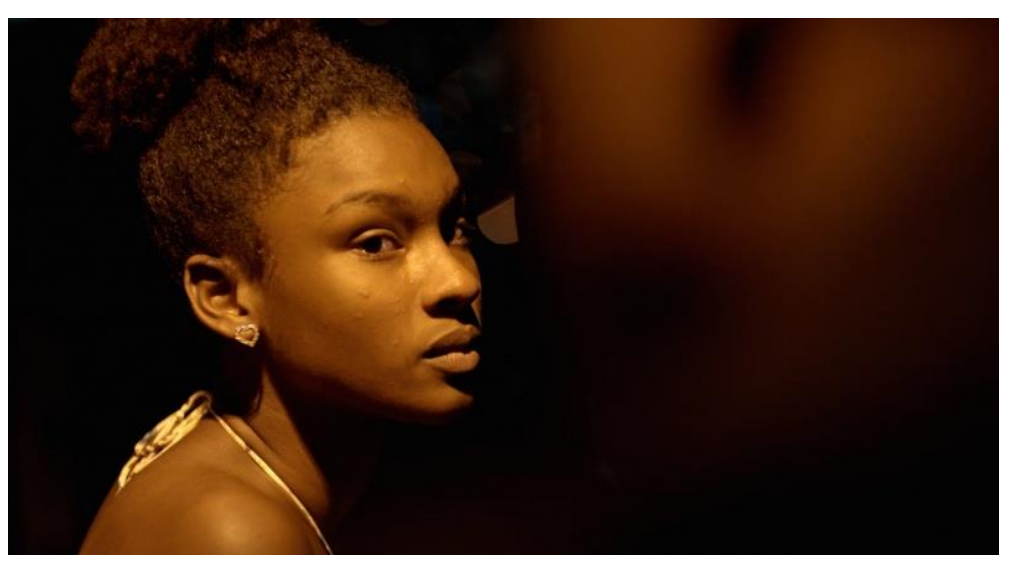
para contar una historia de supervivencia y esperanza a través de dos personajes: la adolescente Tati (Cassia Nascimento) y el antiguo jefe de la favela, Jaca (Kabengele) que, tras salir de la cárcel, busca rehacer su vida fuera del mundo de violencia y narcotráfico que le llevó a ella. El violento, duro y desesperanzador mundo de las favelas está magníficamente retratado, tanto desde la perspectiva femenina, a través de los ojos de Tati y las mujeres que le rodean (madre, abuela y amiga), como masculina. Un mundo al margen de la ciudad baja, mero telón de fondo de luces titilantes en la noche, al que solo algún turista desinformado osaba asomarse y que no fue capaz de pacificar el proyecto del gobierno puesto en marcha en 2008 para expulsar a los narcotraficantes, creando comisarías de policía dentro de las favelas. El proyecto fracasó - por la corrupción y porque no se acompañó de una política social en sanidad y educación- y fue desmantelado justo tras los juegos de Río. Es ese momento, de repunte de la violencia y desesperanza, el que ha elegido Winters, que es también el guionista del film, para situar la acción. Ha trabajado con actores profesionales del mundo de la televisión y con habitantes de la favela Morro dos Prazeres, una de las teóricamente pacificadas, que fue noticia en 2017 por el asesinato de una turista y sirvió de escenario al film Tropa de Élite (José Padilha, 2007), criticado en su momento por exaltar la violencia. El tratamiento contenido que hace de ella Winters en Pacificado, sin dejarse arrastrar y dando protagonismo a los anhelos de sus personajes, es uno de sus grandes aciertos. Y otro más la inserción de ese metafórico y memorable plano de la infinita escalera que trepa hasta lo más alto de la favela: el premio a la mejor fotografía es bien merecido. Quizás en otra situación esta Concha de Oro no hubiera sido cuestionada, pero en esta edición había otra poderosa opción: $L a$ trinchera infinita.

Las quinielas habían apostado por esta magnífica película no solo para la Concha de Oro sino también para el premio al mejor actor (para su protagonista Antonio de la Torre). Aunque fallaron, la calidad del film sí ha sido reconocida con otros dos de los grandes galardones del festival, la Concha de Plata al mejor director, para el trío formado por Aitor Arregi (Oñate, 1977), Jon Garaño (San Sebastián, 1974) y Josemari Goenaga (Ordizia, 1976), y el Premio del Jurado al mejor guion, para Luiso Berdejo y Josemari Goenaga. No obstante, ha sabido a poco. La película arranca en la Guerra Civil española y cuenta la devastadora experiencia de quienes perseguidos como rojos por los sublevados contra la República optaron por esconderse en pequeños recintos dentro de sus casas para evitar las represalias y permanecieron en ese terrible encierro durante décadas con la constante compañía del miedo. Como Manuel Cortés, el 
topo de Mijas, cuya peripecia fue relatada en el documental 30 años de oscuridad (Manuel H. Martin, 2011) que, como explicó Garaño, sirvió de inspiración para hacer este film, trasladando esa realidad a un relato de ficción. A esos topos, y a ninguno en concreto, representa el personaje de Higinio, que interpreta magistralmente Antonio de la Torre, transformación física incluida para mostrar el paso del tiempo (el film se rodó en dos partes con un parón de cinco meses para que él engordara). Y a todas las mujeres que acompañaron $\mathrm{y}$ sufrieron esos encierros el personaje de su esposa Rosa, interpretada por Belén Cuesta, que borda también su papel. La acción discurre en Andalucía, y los dos actores realizaron una minuciosa labor de

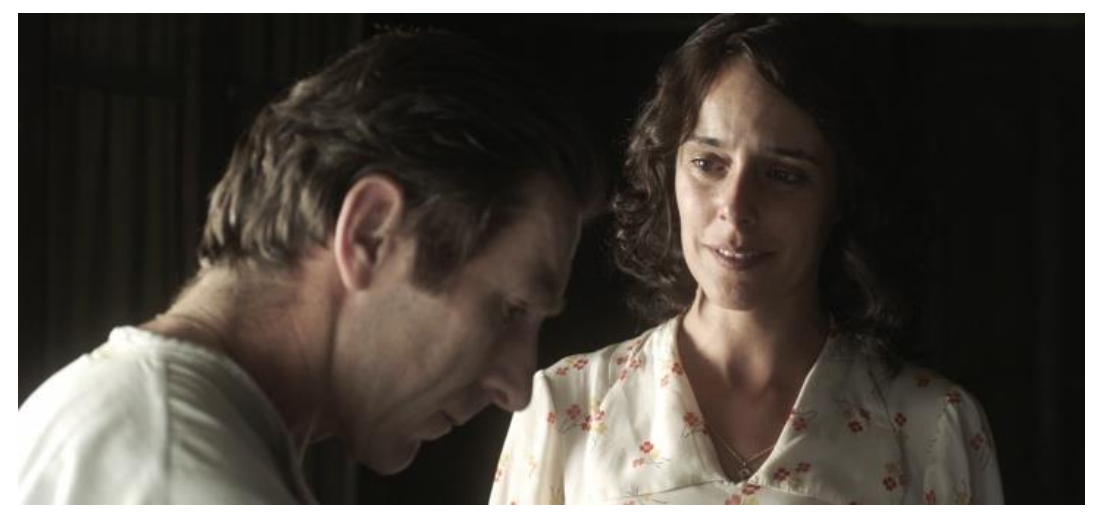
documentación para reproducir el acento andaluz de la época. La forma de narrar es muy original: los distintos hitos y tiempos cronológicos en los que se va desarrollando la acción son introducidos por palabras y definiciones, a modo de entradas de diccionario (campeada, esconder, detención, peligro...). El uso de la luz y de la oscuridad como elementos narrativos son magníficos y también el de la cámara, que construye igualmente relato, agitándose en los iniciales momentos de persecución, calmándose con el encierro del protagonista, estrechando el cuadro hasta dejarlo en una franja horizontal o nublando la imagen para ofrecernos la perspectiva del encerrado. Es un relato sobre el miedo, como han explicado los directores, pero también sobre la persecución y represión franquista desatada en la Guerra Civil y continuada tras ella. El foco se pone en el drama humano, pero el relato historiográfico, que se introduce a través de personajes y elementos externos (las noticias radiadas, la música) que van entrando en el espacio doméstico a lo largo de los 33 años que dura el encierro de Higinio, no es mero telón de fondo. Una gran película, resultado de la colaboración de un equipo vasco-andaluz.

Otro importante film sobre la Guerra Civil ha competido en la Sección Oficial, convirtiendo a este tema en el gran protagonista: Mientras dure la guerra, de Alejandro Amenábar (Santiago de Chile, 1972). Representan ambas películas la mirada de una misma generación de directores sobre este fratricida conflicto, que se aproximan a ella con el ánimo de comprender y de explicar. El film de Amenábar traza un relato en paralelo de la etapa final de la vida de Unamuno y del proceso de ascenso al poder del general Franco tras la muerte de Sanjurjo (dos temas que no quedan del todo bien imbricados, en mi opinión), situando la acción entre julio y octubre de 1936 y culminándola con el famoso discurso de Unamuno en el paraninfo de la Universidad de Salamanca del "venceréis, pero no convenceréis" (o "vencer no es convencer", pues solo se conservan las notas de un discurso improvisado). Amenábar se ha lanzado de lleno a la tarea de tratar de explicar, documentándose sobre la guerra con asesores historiadores - citó en la rueda de prensa a Julián Casanova- y militares - cuyos criterios no siempre fueron coincidentes, señaló-, si bien para el retrato de Unamuno se limitó a consultar bibliografía. Ha declarado que lo que más le sorprendió de los hechos que abordaba era que "a pesar de que los había estudiado en Bachillerato, en realidad no sabía nada", que "toda una generación ha pasado de puntillas sobre estos acontecimientos, no tan alejados en el tiempo, y que es necesario conocer la historia". 
Tuvo que vencer, eso sí, alguna duda inicial: “¿de verdad queremos meternos en esto?”, se dijo al decidirse a recuperar un guion que esperó durante tres años en un cajón. Su film observa la guerra desde la perspectiva de quienes, como Unamuno, rechazaron la deriva radical de la República y apoyaron en un primer momento el levantamiento contra ella entendiéndolo como una vía de vuelta al orden y de regeneración, hasta que el desengaño y la frustración de sus expectativas les permitió tomar conciencia de la verdadera dimensión de lo que estaba pasando. El personaje del general Cabanellas, con su resistencia a suprimir ese "mientras dure la guerra" del nombramiento de Franco como jefe de gobierno y su profética advertencia de que si se le entregaba España iba a creerse que era suya, le ayuda a subrayar esa perspectiva. Al retratar a Franco, interpretado por Santi Prego, Amenábar ha querido hacer "la versión más seria y profunda" del personaje, según explicó en rueda de prensa. Ciertamente, ha retratado a un Franco astuto, que supo esperar su momento y fue tocado por la suerte (o la baraka,

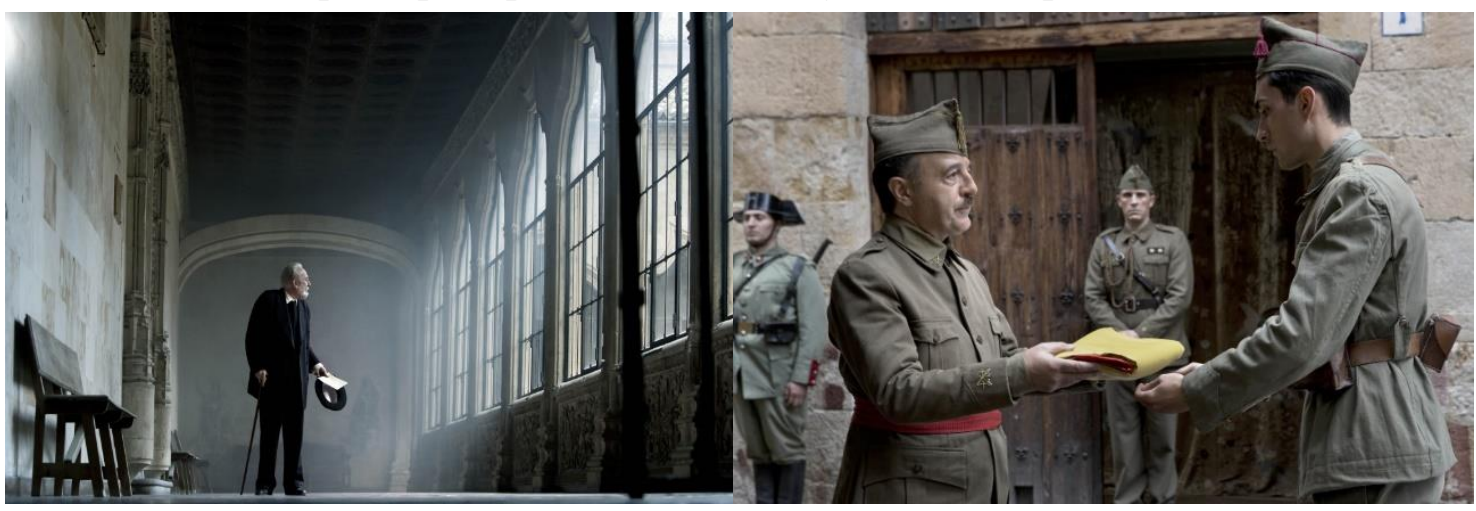

la bendición divina que le permitiría escapar de la muerte, leyenda que se fraguó sobre él cuando luchó en el norte de África), pero también ha recurrido en un momento inicial, innecesariamente en mi opinión, a la típica caricatura cómica apoyada en su voz atiplada para mostrar que no era la "mosquita muerta" que parecía ser y expresar el "desconcierto" que produce su personaje. Buena interpretación de un contenido Karra Elejalde como Unamuno. Y de Eduard Fernández, que llena de fuerza histriónica a Millán Astray. Va a ser un film polémico (la prensa conservadora ha empezado a criticarlo desde su pase en el festival, y hay elementos que también incomodarán a otras miradas ideológicas), pero frente a quienes pretenden inútilmente que no se mire hacia el pasado reciente, hay que aplaudir que un director de la talla de Amenábar se lance a ello con un film que, según ha explicado, pretende también llamar la atención sobre nuestro presente y el repunte del fascismo.

Otros diecisiete films han integrado la Sección Oficial junto a los tres ya mencionados, varios de ellos excelentes películas, $y$ ha habido una nutrida

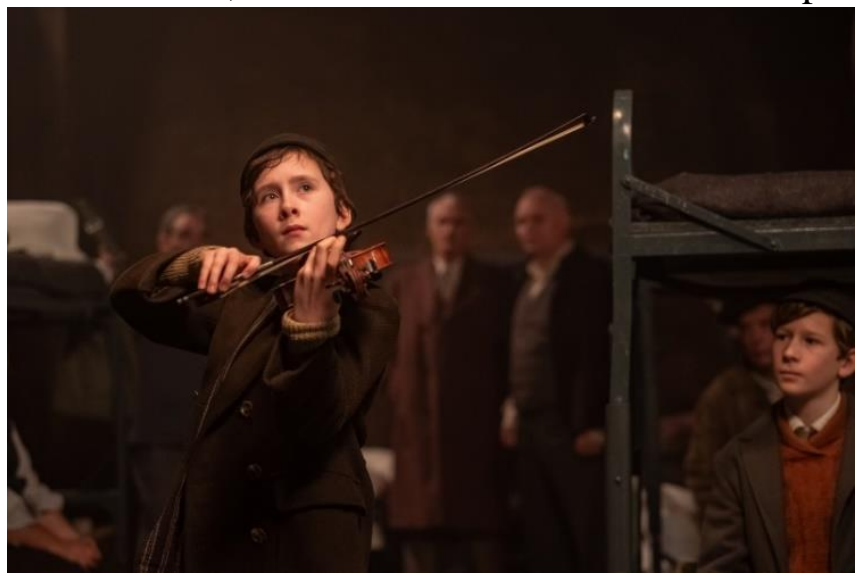
representación del cine social. El film que inauguró oficialmente el festival (siempre fuera de concurso) fue Blackbird (La decisión) de Roger Mitchell, el director de Notting Hill, un drama intenso emocionalmente que aborda abiertamente el tema de la eutanasia, defendiendo la libertad del individuo para decidir sobre su final, con una inmensa Susan Sarandon en el papel protagonista. 
El estreno internacional (también fuera de concurso) de The song of names (La canción de los nombres olvidados) del director canadiense François Girard, con Tim Roth, Clive Owen y Catherine McCormack, puso el broche de clausura. Esta película, de gran belleza y excelente banda sonora, reflexiona sobre la identidad judía a través de la historia de un joven prodigio del violín que se libra de la persecución antisemita nazi, pero que sufre también sus consecuencias. La música ha sido también protagonista de otro film de esta Sección Oficial, Das Vorspiel (La audición), de Ina Weisse, sobre una profesora de violín en un conservatorio alemán obsesionada con un alumno brillante. Entre lo mejor de lo que ha concursado en ella ha estado La hija de un ladrón, de Belén Funes (Barcelona, 1984), con Greta Fernández y Eduard Fernández en los papeles principales (hija y padre en la vida real y en esta ficción). Cine social para retratar la difícil vida de una joven madre, con un padre tóxico y un hermano pequeño tutelado por el Estado, que solo busca formar una familia normal y que la quieran. La excelente

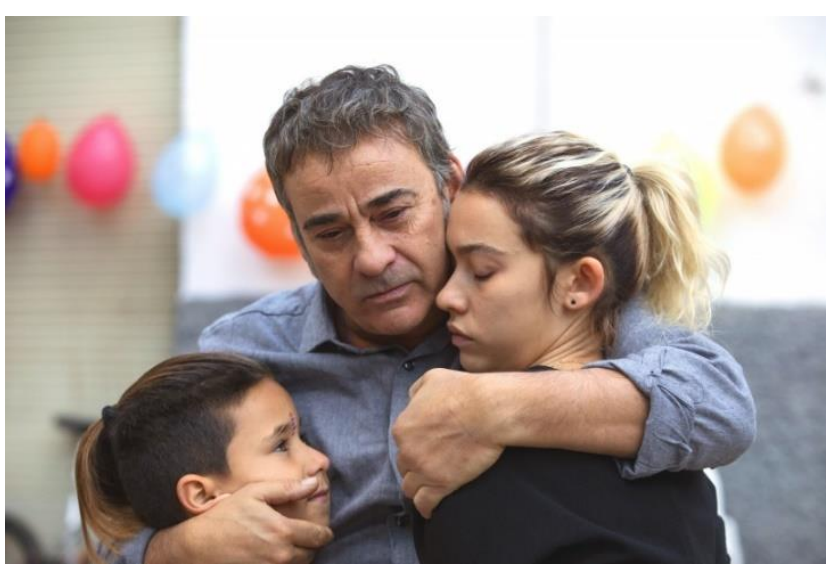
interpretación de Greta Fernández, natural, contenida y expresada magníficamente en su rostro, le ha valido la Concha de Plata a la mejor actriz, premio ex aequo con Nina Hoss, la protagonista de Das Vorspiel. Excelente también ha sido Proxima, coproducción francoalemana dirigida por Alice Winocour (París, 1976), que ha recibido el Premio Especial del Jurado. En este, su tercer largometraje, Winocour habla de las dificultades con que tiene que lidiar una astronauta francesa para atender las exigencias de su profesión y las necesidades de su hija de siete años, e igualmente de los prejuicios machistas que le obligan a tener que demostrar constantemente su capacidad y a ganarse el respeto de sus compañeros (resumidos perfectamente en ese comentario del jefe de su misión espacial, congratulándose públicamente de que al tener una mujer a bordo dispondrán de una buena cocinera). La vida misma. El film es reivindicativo y todo un homenaje a las mujeres astronautas desde la pionera Valentina Kurnikova. En su proyección en el Auditorio del Kursaal (una delicia siempre por su enorme pantalla) el público aplaudió entusiasta cada uno de los nombres e imágenes de las astronautas en misiones espaciales desde los años 80 que precedieron a los títulos de créditos.

La Sección Oficial de un festival como este permite disfrutar también de películas que no llegarán a nuestros circuitos comerciales pero que son fascinantes ventanas abiertas a otras culturas y formas de entender el cine. Dos me han parecido especialmente interesantes: A Dark-Dark Man, de Adilkhan Yerzhanov, un thriller kazajo (o un western centroasiático, según se mire), áspero como la desértica estepa perfectamente fotografiada- que aloja las escenas al aire libre del film, con escasos diálogos y muchos silencios, violento y sin final feliz, retrato de la corrupción mafiosa que infiltra las instituciones del país y a la que se enfrenta un policía lleno de sombras. También la película china La mu yu ga bei (Lhamo y Skalbe) una poética historia de amor imposible sobre dos jóvenes que no logran casarse y sobre el peso de las tradiciones.

Otras propuestas entre los films en competición de la Sección Oficial han sido Il pleuvait des oiseaux ( $Y$ llovieron pájaros) de la directora canadiense Louise Archambault, una historia de segundas oportunidades en la vida, un tanto fría; Mano de 
obra, del mejicano David Zonana, cine social sobre la explotación laboral; The Other Lamb, dirigido por Malgorzata Szumowska, un film extraño, que no ha gustado, de denuncia del fanatismo de las sectas y la opresión de las mujeres; Patrick, coproducción luso-germana dirigida por Gonçalo Waddington sobre una terrible historia de pederastia y violencia; Vendrá la muerte y tendrá tus ojos, del chileno José Luis Torres Leiva, rodada con unos primerísimos planos que se salen de la pantalla, sin casi diálogos, sin un hilo argumental definido y con un final absurdo (al menos yo no he logrado comprender el film); Thalasso, cine de humor francés (a veces muy francés), en donde Michel Houellebecq y Gérard

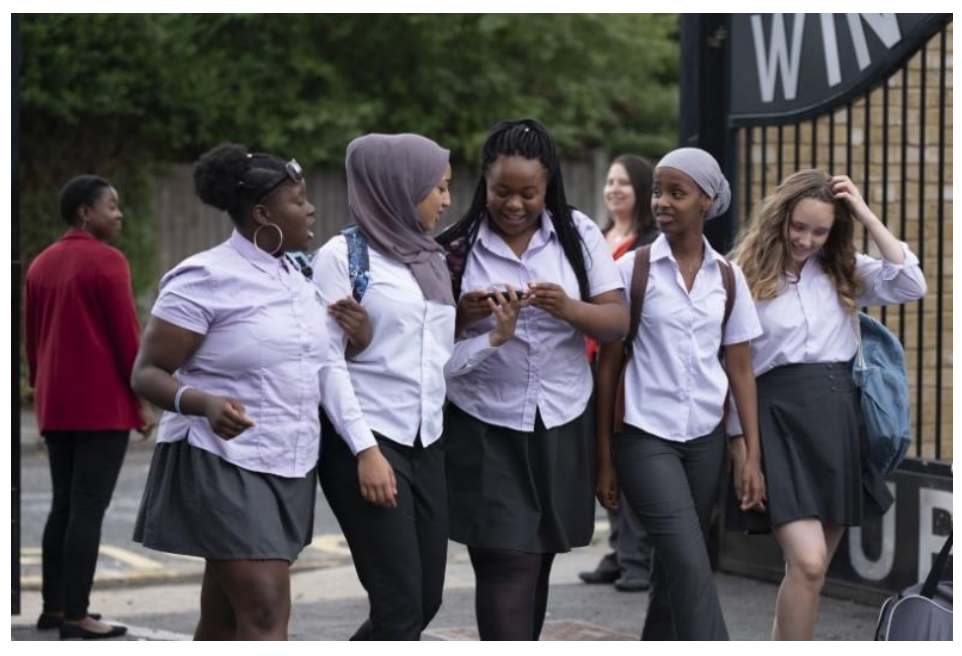
Depardieu, dirigidos por Gillaume Nicloux, hablan sobre la muerte, el sexo y la vejez salpicado de frases lapidarias del tipo "el drama cuando envejeces es que sigues siendo joven"-; y Rocks, otro buen film de cine social, este británico, dirigido por Sarah Gavron, sobre una adolescente (Bukky Bakray) hija de una inmigrante africana, que lleva una vida feliz y normal en el Londres multicultural de nuestros días, y tiene que afrontar repentinamente una situación de desamparo al ser abandonada, ella y su hermano, por su madre. Proyección especial en esta misma sección pero fuera de concurso ha sido Zeroville, de James Franco, que en 2017 ganó la Concha de Oro con The Disaster Artist. En un ejercicio de cine dentro del cine, el film habla de los límites entre realidad y ficción y de las sombras de la industria del cine a través de las andanzas de un estudiante de arquitectura y ex seminarista (interpretado por el propio James Franco) obsesionado con Elizabeth Taylor y Montgomery Clift en Un lugar bajo el sol, que se introduce en el Hollywood de 1969. Toques oníricos, surrealistas, de cine wamp, y reflexiones filosóficas sobre qué es el cine, componen un singular film que ha defraudado a los críticos. Sí ha tenido una buena acogida en cambio Diecisiete, de Daniel Sánchez Arévalo (el director de La gran familia española y de Gordos), una road movie sobre un joven con problemas que emprende un viaje en autocaravana con su hermano y abuela para buscar al perro que le ayudó en su terapia. Otra proyección especial fuera de concurso ha sido La odisea de los giles, de Sebastián Borensztein (Buenos Aires, 1963), film protagonizado por Ricardo Darín -que no se pierde un festival- y su hijo Chino Darín. Ambientado en el corralito argentino de 2001, narra el plan que elaboran un grupo de vecinos víctimas de una estafa, los giles (término equivalente en Argentina a pardillo, persona confiada e ingenua), para recuperar su dinero.

Tres Premios Donostia han sido entregados en esta edición del festival: a Penélope Cruz - cuyo rostro ha inundado la ciudad al componer el cartel principal del certamen-, a Donald Sutherland y a Costa Gravas, premios acompañados de la proyección de una película de cada uno de ellos para rendirles homenaje. Han sido, respectivamente, Wasp Network (La red avispa), de Olivier Assayas, entretenido film pre estrenado en el Festival de Venecia que cuenta - de forma un tanto liosa- la historia (real) de la creación de una red de espionaje cubana en los años 90; The Burnt Orange Heresy (Una obra maestra), de Giusepe Capotondi, un elegante thriller sobre un robo 
de arte, en el que hace un cameo Mike Jagger; y Adults in the room, del gran Costa Gravas, uno de los más importantes exponentes del cine político y autor de films de la talla de Z (1969), Missing (1981), Music Box (1989) o Amen (2001).

Gavras explica en esta película las negociaciones con las instituciones europeas y el FMI que sobre la deuda griega condujo en 2015 como ministro de Finanzas Yanis Varoufakis, llevando al cine las memorias que sobre ellas publicó el economista griego en 2017, de las que toma el título. Es una minuciosa reconstrucción de la batalla de David frente a Goliath que Grecia libró entre el triunfo electoral de Syriza en enero de 2015 y la dimisión en julio de ese mismo año de Varoufakis, interpretado de forma extraordinariamente convincente por Yorgos Arvanitis. El film realiza una demoledora denuncia sobre el comportamiento de los acreedores, sobre los planteamientos macroeconómicos al servicio de los intereses de las élites, las del complejo industrial-

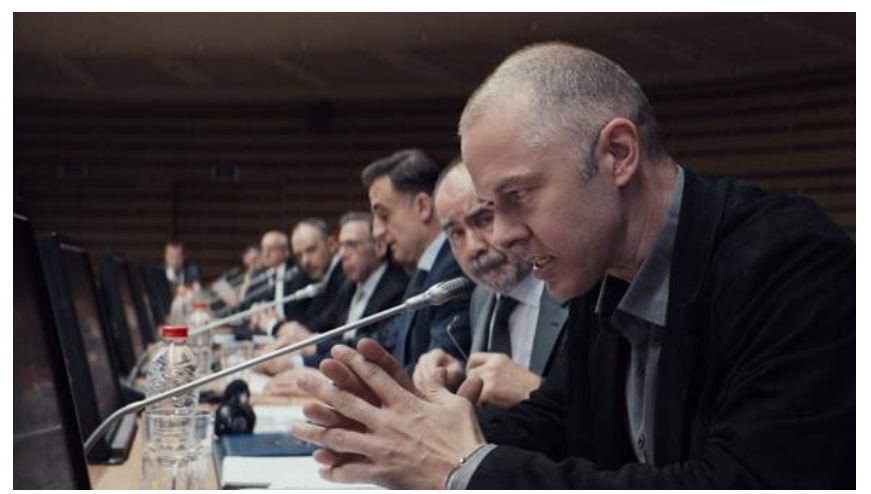
financiero liderado por Alemania, que han guiado a una Unión Europea lanzada sin escrúpulos morales sobre la exhausta Grecia. Mezclando algunas imágenes documentales y acordes de Sirtaki, Gavras narra cronológicamente las esperanzas que abrió la propaganda electoral de Syriza "Si ganamos, no pagaremos la deuda" - y la alarma que despertó entre las élites europeas -"Si ganan ellos, los echamos del euro"-; el intento de cambiar las cosas con la misión encomendada a Varoufakis de "sacar al país de la prisión de la deuda" y el baño de realidad con que se toparon los negociadores griegos; la cólera alemana, encarnada en Wolfgang Schäuble, al tener enfrente a un negociador insólito, outsider, como Varoufakis, ese "izquierdista arrogante" que se negaba a obedecer; la hostilidad, desprecio, y abierta humillación con que fueron tratados los representantes griegos (resumidos en las escenas de la corbata); los intentos de apartar a Varoufakis de las negociaciones, etc. Descarnado, y por momentos satírico, retrato de los dobles lenguajes de la (nada) alta política europea, del exceso de testosterona -resumido en ese "hace falta adultos en esta sala" que al parecer dijo Christine Lagarde-, del peso de los estereotipos (los derrochadores griegos frente a los trabajadores alemanes), del poder de los tecnócratas -"la libertad es esencial para nuestras democracias, pero ahora hay que sustituirla por un sistema de orden", le dice el mensajero de Merkel a Varoufakis-. Y de la dignidad griega: "la crisis continúa y el pueblo sobrevive heroicamente", frase lapidaria que cierra el film. Una película hecha para no olvidar la gran tragedia griega, que es una tragedia europea. Un film expresión, y a la vez instrumento, de memoria colectiva. Muy interesante, a pesar de que su largo metraje y minuciosidad pueda limitar su difusión.

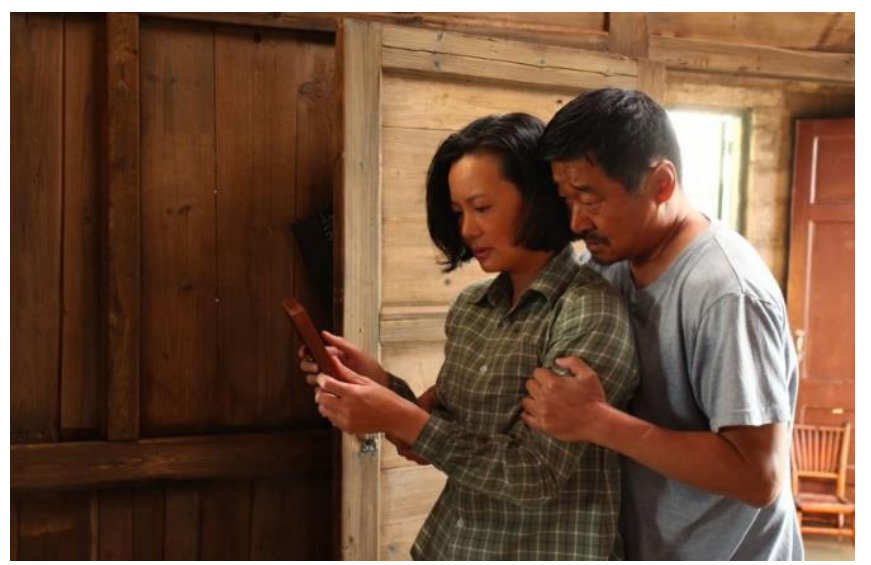


La siempre interesantísima sección de Perlas, que proyecta películas premiadas en otros grandes festivales, ha ofrecido este año un conjunto de excelentes films, varios de gran interés para historiadores. Uno de los mejores, aclamado por crítica y público, ha sido Di jiu tian chang (Hasta siempre, hijo mío), dirigido por Wang Xiaoshuai, un fresco sobre la historia de China desde los años ochenta hasta la actualidad, relatada desde la perspectiva de la gente sencilla. A través de la vida de una pareja de obreros golpeada trágicamente por la muerte de su hijo, y con un relato no lineal que nos lleva constantemente adelante y atrás en el tiempo, el film explica muy bien los límites de la modernización introducida por Deng Xiaping, que dejó atrás la Revolución Cultural pero siguió persiguiendo cualquier atisbo de occidentalización; los estragos sociales de la política del hijo único, singularmente en los sectores más humildes de la población, aquellos que no podían costear las multas ni arriesgarse a represalias laborales; el férreo control social que tras la supresión de la comuna maoísta se trasladó a las fábricas, ejerciendo sus gestores el mismo papel vigilante que el que desempeñaron antes los mandos de las comunas; los efectos de la introducción de la economía de mercado en el empleo; y finalmente el boom inmobiliario. Todo ello constituye no el telón de fondo del relato sino los hechos que determinan la vida de los protagonistas. La familia, el destino, la amistad y la culpa son los grandes temas sobre los que habla este emotivo -y de muy largo metraje- film.

Otra de las joyas de Perlas ha sido Seberg, de Benedict Andrews, film

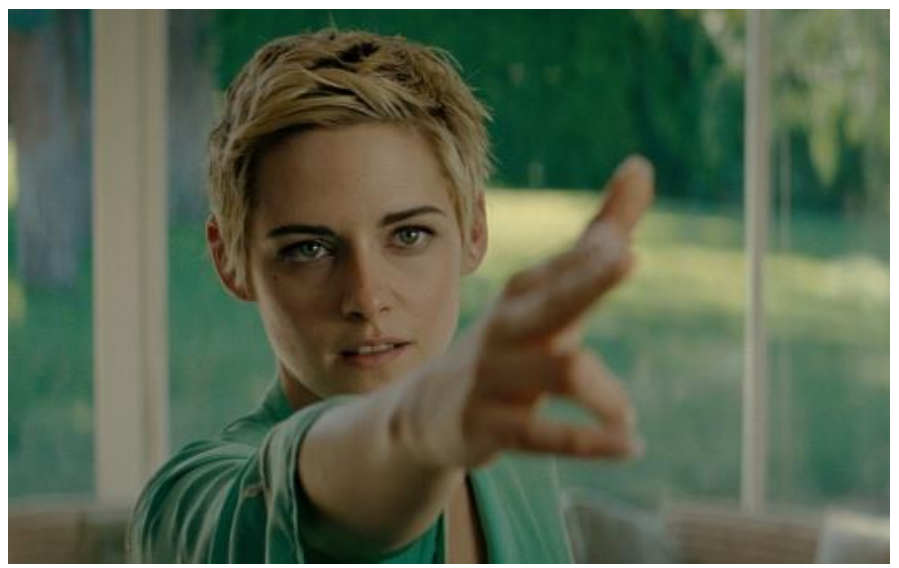
protagonizado por Kristen Stewart. Narra la historia de la actriz estadounidense Jean Seberg (1938-1979), musa de la Nouvelle Vague e intérprete de Jeanne d'Arc (1957), Bonjour tristesse (1958), À bout de souffle (1960) y Lilith (1964), que fue una víctima del programa COINTELPRO del FBI, desarrollado entre 1956 y 1971, en plena Guerra Fría, para neutralizar grupos de activistas políticos radicales. Estuvo dirigido primero contra el partido comunista, pero rápidamente colocó en su foco a grupos de la New Left, como los Weatherman, y organizaciones de defensa de los derechos civiles, entre ellos los Black Panther. Seberg, que simpatizó con este grupo y lo financió, se convirtió en objetivo de ese programa de caza de brujas (como explica ya metafóricamente la primera escena del film, con Juana de Arco quemándose en la hoguera). De ello habla la película, explicando cómo el FBI, el de Hoover y Frank Ellroy, destruyó su vida. De hecho, sugiere que la misteriosa muerte de Seberg (atribuida a un suicidio por barbitúricos. Fue encontrada dentro de su coche en una calle de París) fue responsabilidad del FBI. Magníficamente ambientada, con unas convincentes interpretaciones y un ajustado metraje, retrata bien esa sociedad fracturada entre una juventud inconformista que quería hacer la revolución, resumida en Seberg y sublimada en aquel corte de pelo que se convirtió en todo un símbolo, y la América blanca de sus progenitores, la del American way of life, encarnada en ese rabioso agente del FBI (Vince Vaugh) en pie guerra contra todo lo que la amenazara. Ofrece eso sí una imagen amable de los Black Panther, mostrando su programa educativo y a activistas que defendían la cooperación interracial frente a línea oficial del partido. El uso de imágenes documentales refuerza el retrato de la época, y el film tiene una lectura desde el 
presente. Como explicó su director en rueda de prensa, ha tratado de hacer una denuncia contra "la cultura de la vigilancia que vivimos hoy día y estaba [entonces] en sus albores", explicar cómo se puede "fabricar información" para destruir el activismo político y la disidencia, lo que hoy llamaríamos fake news.

También programada en Perlas, otra de las grandes películas que se han visto en

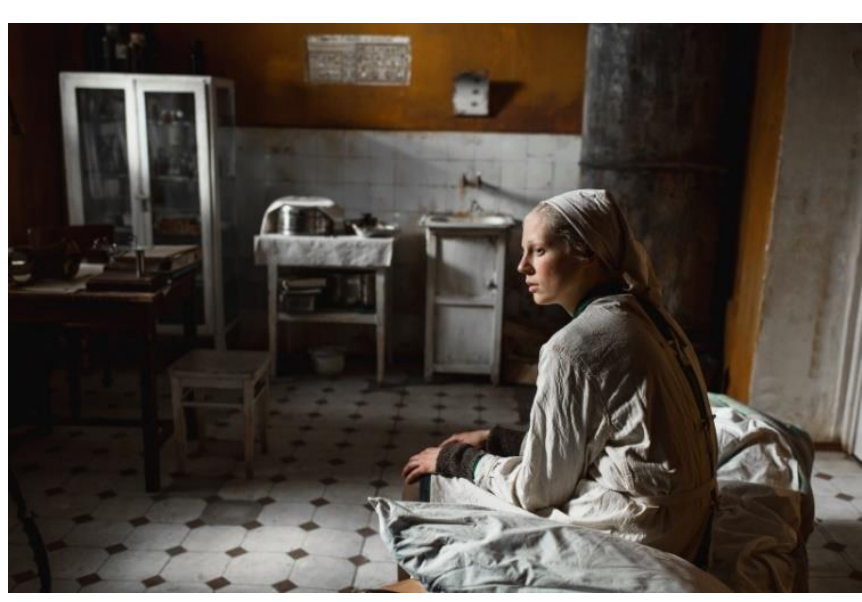
este festival es Beanpole (Una gran mujer), del joven director ruso Kantemir Balagov. Ambientada en el devastado Leningrado de 1945, finalizada ya la guerra y dejado atrás los terribles días del asedio nazi, en el que cientos de miles de personas murieron de hambre y frío, el film cuenta la relación entre dos mujeres, un médico y el hijo de una dirigente del PCUS, y sus intentos de retornar a una vida normal que no puede ya librarse de la huella de la guerra. Habla de muchas cosas, pero especialmente de las heridas físicas y psicológicas que deja la guerra, singularmente en las mujeres. Sobrecogedora, dura, una película de miradas y de sonidos secos, de esas que se recuerdan. Otras excelentes ofertas de Perlas han sido el film coreano Parasite de Bong Joon-ho, Palma de Oro en la pasada edición del Festival de Cannes; Les Misérables, dirigido por Ladj Ly; Portrait de la jeune fille en feu (Retrato de una mujer en llamas), producción francesa dirigida por Céline Sciamma; The Laundromat (Dinero sucio), de Steven Sonderbergh, protagonizada por la gran Meryl Streep; la última película de Ken Loach, Sorry We Missed You, denuncia de la explotación laboral que acompaña a los nuevos trabajos temporales y del impacto que tienen sobre la vida familiar, singularmente en los niños; y finalmente Hors normes (Especiales), de Éric Toledano y Olivier Nakache, los autores de Intocable, cine social de denuncia, con toques de comedia (sin serlo propiamente), que nos acerca el mundo del autismo severo y es a la vez un canto a la solidaridad.

Más de 200 películas han compuesto la oferta de este año, repartidas entre las diferentes secciones del festival (New Directors, Zabaltegi, Horizontes Latinos, Nest Film Students, Culinary Zinema, Zinemira...), incluida la retrospectiva dedicada al mejicano Roberto Gavaldón, el director de La barraca (1945), Macario (1960) o La rosa

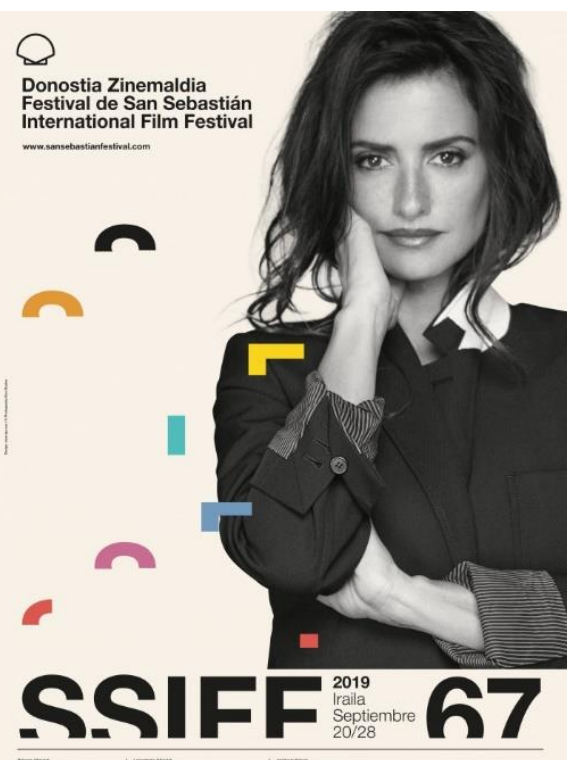

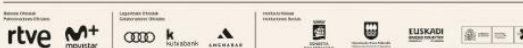
blanca (1972). Tan solo añadiré que en la sección Made in Spain se ha proyectado el documental Zubiak (Puentes) de Jon Sistiaga y Alfonso Cortés Cabanillas sobre el atentado de ETA contra Juan Mari Jauregi, relatado por su viuda y la persona que le asesinó, y que forma parte de la serie ETA, el final del silencio. Y también que una de las novedades de esta edición del festival ha sido la recuperación de una antigua tradición perdida, la inclusión de una película sorpresa, que se ha proyectado por primera vez de forma simultánea en otras cinco ciudades (Madrid, Barcelona, Sevilla, 
Zaragoza y Valencia), como primicia, antes de su estreno comercial. La película en cuestión, cuyo título no se desveló hasta mitad del festival y se pasó la última jornada, ha sido la polémica Joker, dirigida por Todd Phillips, con Joaquin Phoenix y Robert de Niro entre sus intérpretes, y ganadora de un León de Oro en Venecia. Fue el broche de una nuevamente exitosa edición, que volverá a ser igual de estimulante, seguro, el próximo año. 